\title{
On the article "Weathered potassic volcanic rocks as protoliths of the hematitic phyllites of the southern Serra do Espinhaço (MinasGerais)": a discussion
}

Alexandre Raphael Cabral ${ }^{1,2^{*}}$ Francisco Robério de Abreu ${ }^{3}$

\author{
${ }^{1}$ Universidade Federal de Minas Gerais \\ Instituto de Geociências \\ Centro de Pesquisas Professor Manoel Teixeira \\ da Costa \\ Belo Horizonte MG Brazil \\ CEP 31270-901 \\ ${ }^{2}$ Centro de Desenvolvimento da Tecnologia \\ Nuclear \\ Belo Horizonte MG Brazil \\ CEP 31270-901 \\ ${ }^{3}$ Pesquisador Autônomo \\ Sustain Geologia \\ Rua Tereza Mota Valadares 503/502 \\ Belo Horizonte MG Brazil \\ CEP 30575-160 \\ * Corresponding author \\ arcab@ufmg.br
}

\begin{abstract}
RESUMO
Chaves e Knauer (2020) apresentaram três novas análises químicas de rocha total de filito hematítico, uma rocha metamórfica singular da Serra do Espinhaço meridional. Com base em suas três amostras e uma seleção de outras três amostras da literatura, Chaves e Knauer propuseram que a singularidade geoquímica da rocha - ou seja, altos teores de $\mathrm{K}_{2} \mathrm{O}, \mathrm{Al}_{2} \mathrm{O}_{3}$ e $\mathrm{Fe}_{2} \mathrm{O}_{3}$, e depleção em $\mathrm{SiO}_{2}$ - representaria intemperismo de basalto alcalino rico em feldspatoide. Esta contribuição é uma discussão de seus novos dados, cujos teores em elementos traços estão em desacordo com aqueles de um protólito vulcânico potássico, derivado do manto, para o filito hematítico. Suas razões $\mathrm{Nb} / \mathrm{Th}$ de $\sim 3$ e razões $\mathrm{La} / \mathrm{Yb}$ normalizadas por condrito de $\sim 9$ 17, por exemplo, são típicas da crosta continental. Também apontamos aspectos que escaparam à atenção de Chaves e Knauer (2020), um dos quais é a ocorrência ubíqua de turmalina no filito hematítico.

Palavras-chaves: Filito hematítico, magmatismo alcalino, intemperismo, metamorfismo, Serra do Espinhaço.
\end{abstract}

\section{ABSTRACT}

Chaves and Knauer (2020) have presented three new whole-rock chemical analyses of phyllitic hematite, a unique metamorphic rock of the southern Serra do Espinhaço. Based on their three samples and a selection of other three samples from the literature, Chaves and Knauer have proposed that the geochemical uniqueness of the rock - i.e., high contents of $\mathrm{K}_{2} \mathrm{O}, \mathrm{Al}_{2} \mathrm{O}_{3}$ and $\mathrm{Fe}_{2} \mathrm{O}_{3}$, and depletion in $\mathrm{SiO}_{2}$ - would represent a weathered, feldspathoid-rich alkaline basalt. This contribution is a discussion of their new data, the trace-element contents of which are at odds with those of a potassic, mantle-derived volcanic protolith for the hematitic phyllite. Its $\mathrm{Nb} / \mathrm{Th}$ ratios of $\sim 3$ and chondrite-normalised $\mathrm{La} / \mathrm{Yb}$ ratios of $\sim 9-17$, for instance, are typical of the continental crust. We also point out aspects that escaped the attention of Chaves and Knauer (2020), one of which is the ubiquitous occurrence of tourmaline in the hematitic phyllite.

Keywords: Hematitic phyllite, alkaline magmatism, weathering, metamorphism, Serra do Espinhaço

\section{INTRODUCTION}

Chaves and Knauer (2020) have recently published an article that presents two unsharp transmitted-light photomicrographs and whole-rock chemical analyses for three samples of hematitic phyllite, a sui generis metamorphic rock of the southern Serra do Espinhaço. Based on their new data and an incomplete data compilation, Chaves and Knauer
(2020) have concluded that the protolith of the hematitic phyllite would have been a mantlederived, but weathered, feldspathoid-rich alkaline basalt. Here, we discuss their new data, the trace-element signature of which is inconsistent with an alkali-basalt protolith, even if affected by deep weathering. We further point out aspects that escaped the attention of Chaves and Knauer (2020). 

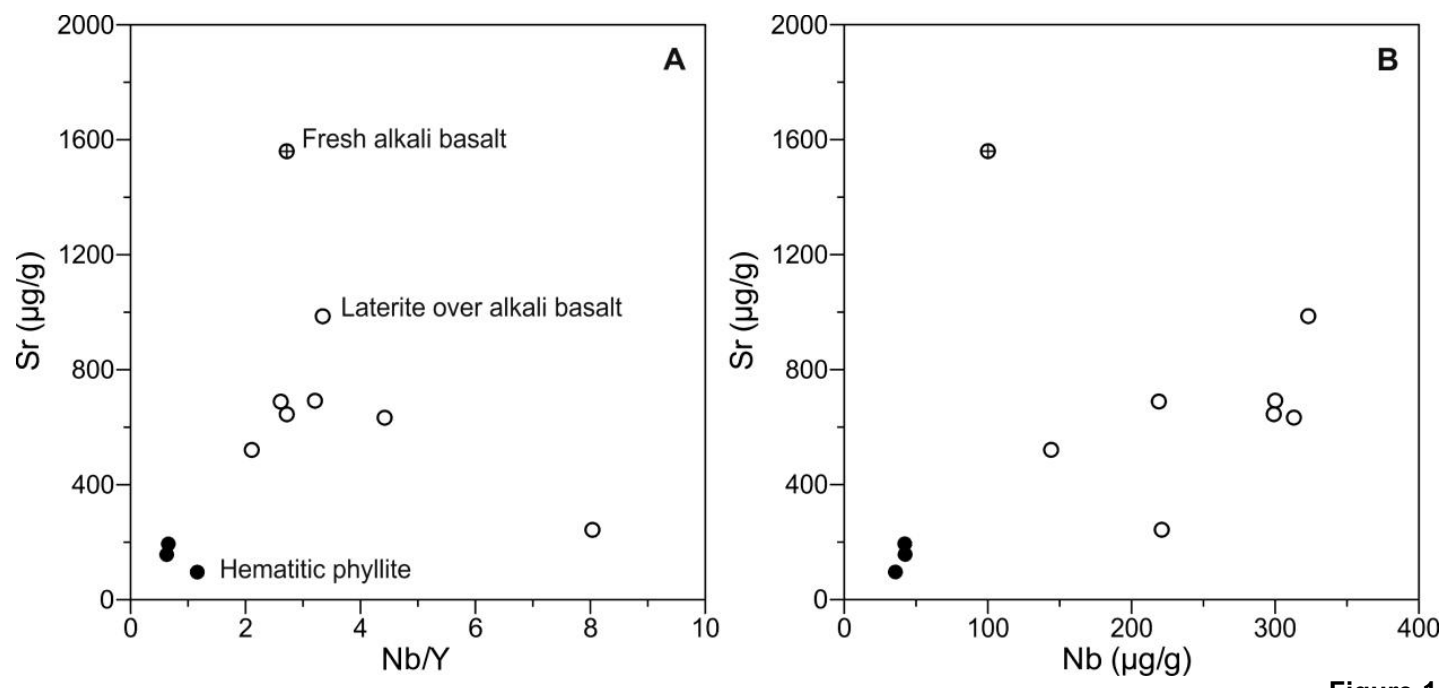

Plots of $\mathrm{Nb} / \mathrm{Y}$ vs. $\mathrm{Sr}(\mathrm{A})$ and $\mathrm{Nb}$ vs. $\mathrm{Sr}(\mathrm{B})$ for the three samples of hematitic phyllite reported in Chaves and Knauer (2020), in comparison with fresh alkali basalt and its laterite profile (SANEMATZU et al. 2011).

\section{DISCUSSION}

One of the three samples reported in Chaves and Knauer (2020) plots within the alkalinebasalt field of the $\mathrm{Nb} / \mathrm{Y}$-vs.- $\mathrm{Zr} / \mathrm{TiO}_{2}$ diagram of Floyd and Winchester (1978). According to Chaves and Knauer (2020, p. 191), the aforementioned diagram would indicate that all their samples would have had chemical compositions similar to feldspathoid-rich alkaline basalt, which would have been modified by weathering before metamorphism. Weathering, however, is known to affect the mobility of $\mathrm{Y}$, leading to $\mathrm{Nb} / \mathrm{Y}$ ratios that span all compositions, from the andesite to the basanitenephelinite fields of the $\mathrm{Nb} / \mathrm{Y}-v s .-\mathrm{Zr} / \mathrm{TiO}_{2}$ diagram of Floyd and Winchester (1978). This is the case of tholeiitic lavas that show all degrees of weathering from fresh olivine basalt to bauxite and Fe-oxide crust (HILL et al., 2000). Figure 1A further illustrates variable $\mathrm{Nb} / \mathrm{Y}$ ratios from a lateritic profile over alkali basalt (SANEMATZU et al., 2011), which is typically enriched in Sr (BERGMAN, 1987). However, the purported samples of alkali-basalt-derived hematitic phyllite are not only depleted in $\mathrm{Sr}$ (Fig. 1A), but also in $\mathrm{Nb}$ (Fig. 1B). Despite depletion, $\mathrm{Sr}$ is considerably retained in lateritic profiles in a way that the alkali-basalt $\mathrm{Sr}$ signature can be recognised (SANEMATZU et al., 2011). Partial retention of $\mathrm{Sr}$ in lateritic profiles is due to the formation of aluminum-phosphate-sulfate (APS) minerals, such as goyazite (SANEMATZU et al., 2011). Even if extreme weathering erased the $\mathrm{Sr}$ signal, the characteristically elevated $\mathrm{Nb}$ contents of alkaline rocks would have been enhanced in weathered rocks (Fig. 1B; VALETON et al., 1997, SANEMATZU et al., 2011). Unless the weathering claimed by Chaves and Knauer (2020) was uniquely capable of effectively leaching $\mathrm{Nb}$, the $\mathrm{Nb}$ contents of their samples, between about 36 and $42 \mu \mathrm{g} / \mathrm{g} \mathrm{Nb}$, rule out any weathered alkali-basalt protolith.

Two other lines of evidence for an alkaline volcanic protolith have been advanced by Chaves and Knauer (2020). First, the high contents of $\mathrm{K}_{2} \mathrm{O}$ of their three samples, between 7.1 and $8.3 \%$, would be comparable to the average $\mathrm{K}_{2} \mathrm{O}$ contents of leucitite and lamproite (Table 2 of CHAVES; KNAUER, 2020). Apart from $\mathrm{Al}, \mathrm{Ti}$ and $\mathrm{Fe}$, the major elements would have been leached during weathering, but not $\mathrm{K}$, the contents of which would have been preserved because of the absence of plants in the Precambrian. One wonders at such a preservation of $\mathrm{K}$ contents, whereas the $\mathrm{Nb}$ signature of a K-rich, mantlederived rock would have been erased. As mentioned in the previous paragraph, the $\mathrm{Nb}$ signal should have been enhanced in weathering profiles over such rocks. Niobium and $\mathrm{Th}$ are so poorly mobile during oxidative weathering that $\mathrm{Nb} / \mathrm{Th}$ ratios of lateritised products show little variation in relation to the fresh rock (Fig. 2). Most lateritised samples of alkali basalt of Figure 2 have $\mathrm{Nb} / \mathrm{Th}$ ratios that are close to the fresh-rock $\mathrm{Nb} / \mathrm{Th}$ ratio of $\sim 8$, which is typical of primitivemantle-derived rocks (COLLERSON; KAMBER, 1999). In contrast, the samples reported 
by Chaves and Knauer (2020) have $\mathrm{Nb} / \mathrm{Th}$ ratios of $\sim 3$ (Fig. 2), a value that is characteristic of the continental crust (COLLERSON; KAMBER, 1999; RUDNICK; GAO, 2003). Second, the chondrite-normalised pattern of the rare-earth elements (REE), as shown in Figure 4 of Chaves and Knauer (2020) as evidence for an alkaline-magma derivation of their samples, is misleading. Their samples bear resemblance to the chondrite-normalised pattern of the upper continental crust - UCC (Fig. 3), in agreement with their $\mathrm{Nb} / \mathrm{Th}$ ratios. Potassic lavas have chondrite-normalised $\mathrm{La} / \mathrm{Yb}$ ratios $\left[(\mathrm{La} / \mathrm{Yb})_{\mathrm{cn}}\right]$ above 20 , whereas the $(\mathrm{La} / \mathrm{Yb})_{\mathrm{cn}}$ values of Chaves and Knauer's samples are below 20, overlapping that of the UCC (Fig. 4).

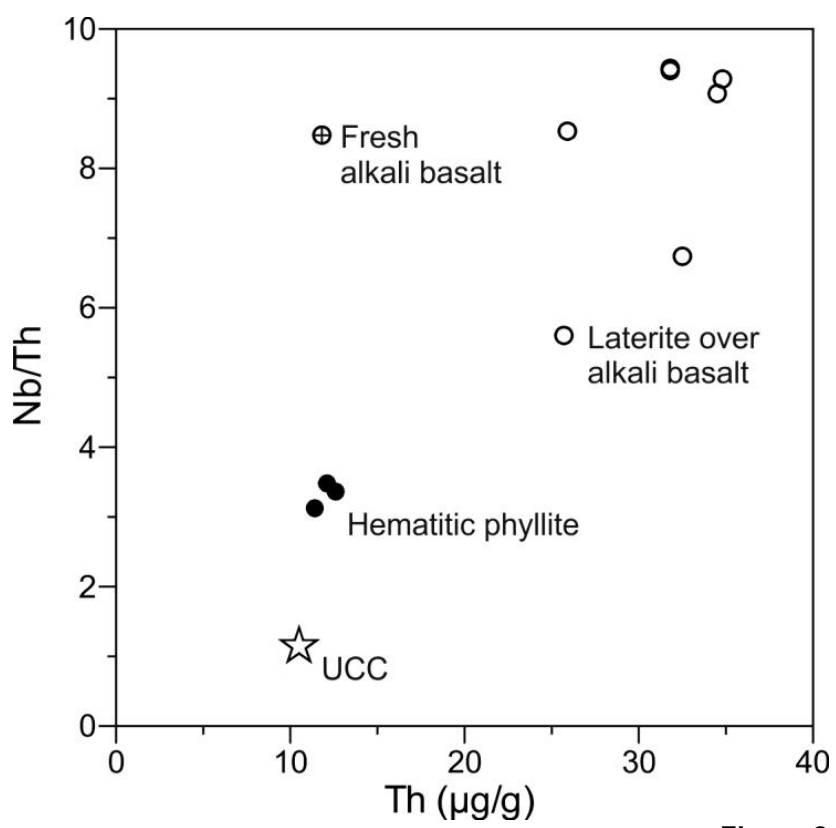

Plot of Th vs. Nb/Th for the three samples of hematitic phyllite reported in Chaves and Knauer (2020), in comparison with fresh alkali basalt and its laterite profile (SANEMATZU et al., 2011), and the upper continental crust - UCC (RUDNICK; GAO,

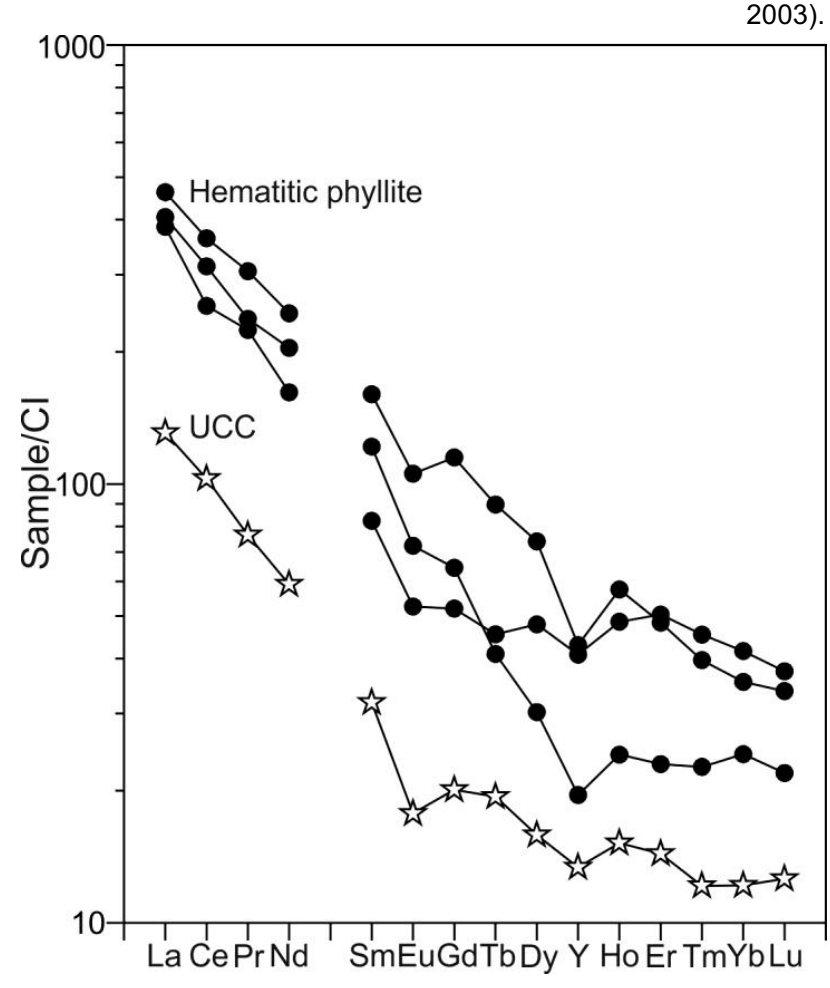

Figure 3

Chondrite-normalised plot of the rare-earth elements for the three samples of hematitic phyllite reported in Chaves and Knauer (2020), in comparison with the upper continental crust - UCC (RUDNICK; GAO 2003). Chondrite values are from McDonough and Sun (1995) 


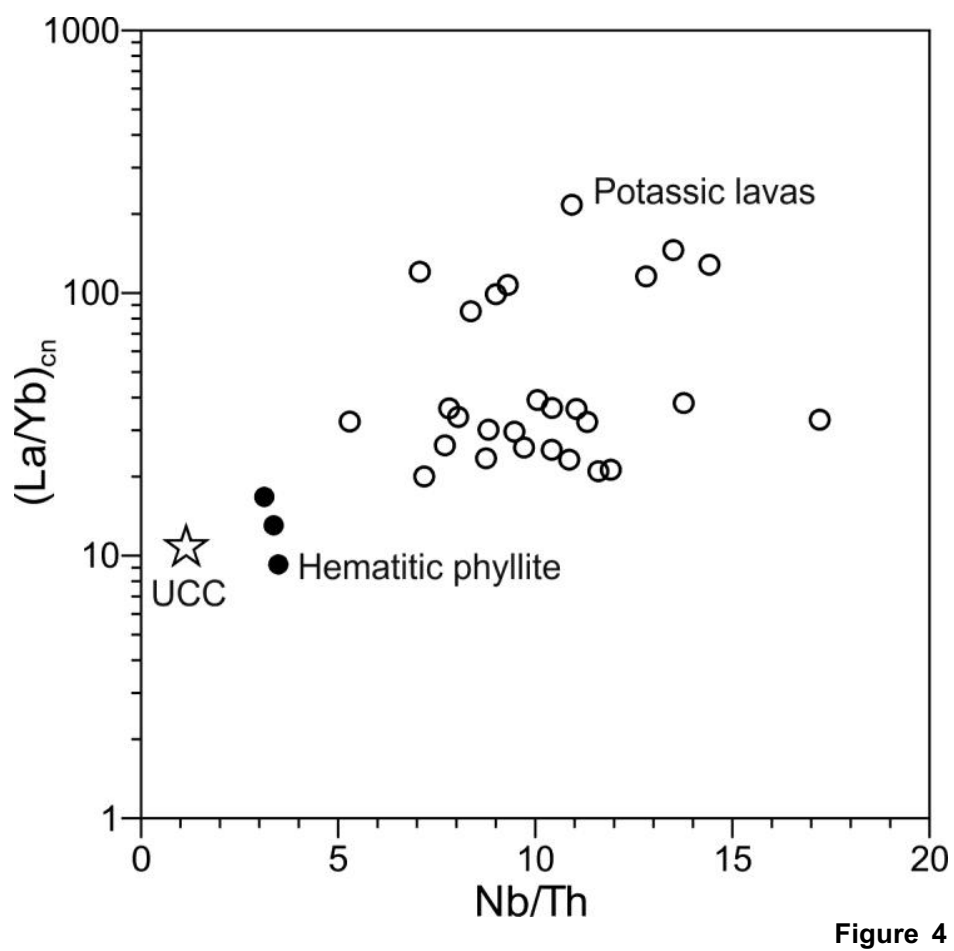

Plot of $\mathrm{Nb} / \mathrm{Th}$ vs. chondrite-normalised $\mathrm{La} / \mathrm{Yb}\left[(\mathrm{La} / \mathrm{Yn})_{\mathrm{cn}}\right]$ for the three samples of hematitic phyllite reported in Chaves and Knauer (2020), in comparison with potassic lavas (MITCHELL; BELL, 1976), and the upper continental crust - UCC (RUDNICK; GAO, 2003).

Two aspects that are relevant to the petrogenesis of hematitic phyllite escaped the attention of Chaves and Knauer (2020). First, only three of the seven samples of hematitic phyllite that are reported in Cabral et al. (2012) have been considered by Chaves and Knauer (2020) - see their Table 1 and Figures 4 and 5. Those four samples that were overlooked plot within the rhyolite-dacite field of the $\mathrm{Nb} / \mathrm{Y}$-vs.-Zr/Ti diagram of Pearce (1996) - see Figure 5b of Cabral et al. (2012). Taking into account all samples in the data set of Cabral et al. (2012), two protoliths for the hematitic phyllite can be distinguished: a basic rock and an acidic rock. Second, the widespread tourmalinisation in the southern Serra do Espinhaço, which is expressed in the hematitic phyllite as disseminations and pockets (CORRENS, 1932; DERBY, 1879, 1899, 1900a; MORAES; GUIMARÃES, 1931; CABRAL et al., 2011). Derby (1900b) noted in the hematitic phyllite and enclosing clastic rocks "a new formation of monazite such as has been shown for tourmaline" (DERBY 1900b, p. 219). The hematitic-phyllite-hosted tourmaline, which occurs as disseminations and concentrations (in pockets), has chemical compositions that are characteristic of metaevaporitic tourmaline of non-marine nature (Fig. 5). The presence of tourmaline in a matrix of fine-grained muscovite can thus be understood as $\mathrm{B}$ and $\mathrm{K}$ overprint on volcanic protoliths (CABRAL et al., 2012). Therefore, the presence of high amounts of $\mathrm{K}_{2} \mathrm{O}$ in the hematitic phyllite cannot be linked to potassic lavas, as interpreted by Chaves and Knauer (2020). Finally, Chaves and Knauer (2020) overlooked the work of Derby (1900a). He noted not only the peculiar presence of tourmaline in the hematitic phyllite, but also proposed that the phyllite "may result from the alteration of rocks, both massive and clastic, that had been decomposed and leached in situ (...)" (DERBY, 1900a, p. 213). 


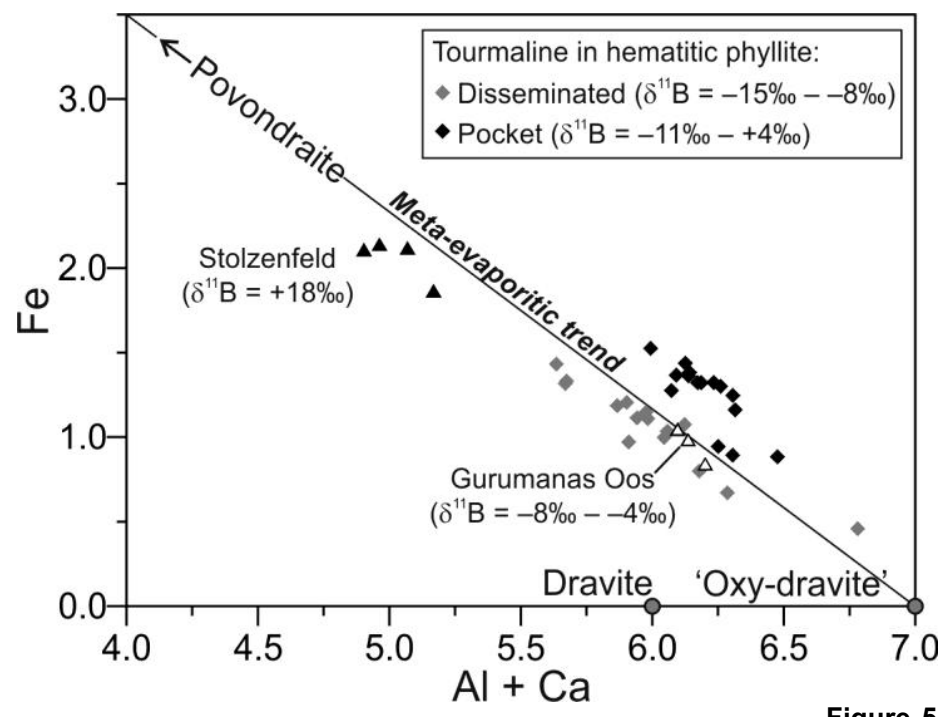

Plot of $\mathrm{Al}+\mathrm{Ca}$ vs. Fe (HENRY et al., 2008), in atoms per formula unit of tourmaline, for tourmaline in hematitic phyllite that is presented in Cabral et al. (2012). The povondraite-'oxy-dravite' join represents the meta-evaporitic trend (HENRY et al., 2008), along which disseminated tourmaline and pocket tourmaline plot. The latter is offset to higher contents of Fe. Metaevaporitic tourmaline from Namibia, Stolzenfeld and Gurumanas Oos (HENRY et al., 2008), is shown for comparison. The boron isotopic compositions of the Namibian tourmaline and those hosted in the hematitic phyllite of the southern Serra do Espinhaço are from Palmer and Slack (1989), and Cabral et al. (2012), respectively. The predominance of negative $\delta^{11} \mathrm{~B}$ values in the hematitic-phyllite tourmaline and its meta-evaporitic composition are evidence for non-marine evaporitic $B$ in the K-rich fluid overprint (CABRAL et al., 2017).

\section{CONCLUSIONS}

The new data presented by Chaves and Knauer (2020) do not support a mantlederived, $\mathrm{K}_{2} \mathrm{O}$-rich volcanic protolith for the

\section{ACKNOWLEDGEMENTS}

We express our gratitude to Prof. Jorge C. de Lena, Editor-in-Chief of Geochimica Brasi-

\section{REFERENCES}

BERGMAN S.C. Lamproites and other potassiumrich igneous rocks: a review of their occurrence, mineralogy and geochemistry. In: J.G. Fitton; B.G.J. Upton (eds.) Alkaline igneous rocks. Geological Society Special Publication, 30, The Geological Society of London, 103-190, 1987. https://doi.org/10.1144/GSL.SP.1987.030.01.08

CABRAL A.R.; LEHMANN B.; TUPINAMBÁ M.; WIEDENBECK M.; BRAUNS M. Geology, mineral chemistry and tourmaline $\mathrm{B}$ isotopes of the Córrego Bom Sucesso area, southern Serra do Espinhaço, Minas Gerais, Brazil: Implications for $\mathrm{Au}-\mathrm{Pd}-\mathrm{Pt}$ exploration in quartzitic terrain. J. Geochem. Expl., 110, 260-277, 2011

https://doi.org/10.1016/j.gexplo.2011.06.007

CABRAL A.R., WIEDENBECK M., KOGLIN N., LEHMANN B., DE ABREU F.R. Boronisotopic constraints on the petrogenesis of hematitic phyllite in the southern Serra do Espinhaço, Minas Gerais, Brazil. Lithos, 140141:224-233, 2012 rock known as hematitic phyllite in the southern Serra do Espinhaço.

liensis, for his editorial handling.

https://doi.org/10.1016/j.lithos.2012.01.011

CABRAL A.R.; TUPINAMBÁ M.; ZEH A., LEHMANN B.; WIEDENBECK M.; BRAUNS M.; KWITKO-RIBEIRO R. Platiniferous goldtourmaline aggregates in the gold-palladium belt of Minas Gerais, Brazil: implications for regional boron metasomatism. Miner. Petrol., 111:807-819, 2017

https://doi.org/10.1007/s00710-017-0496-0

CHAVES A.O.; KNAUER L.G. Vulcânicas potássicas intemperizadas como protólitos dos filitos hematíticos da Serra do Espinhaço Meridional (Minas Gerais). Geochim. Bras., 34:183-194, 2020

https://doi.org/10.21715/GB23582812.2020342 183

COLLERSON K.D.; KAMBER B.S. Evolution of the continents and the atmosphere inferred from $\mathrm{Th}-\mathrm{U}-\mathrm{Nb}$ systematics of the depleted mantle. Science, 283:1519-1522. 1999

https://doi.org/10.1126/science.283.5407.1519

CORRENS C.W. Über die Diamantlagerstätten des Hochlandes von Diamantina, Minas Geraes, 
Brasilien. Z. prakt. Geol., 40:161-168, 177181,1932

DERBY O.A. Observações sobre algumas rochas diamantiferas da provincia de Minas Geraes. Archivos do Museu Nacional (Rio de Janeiro), 4:121-132, 1879

DERBY O.A. On the association of argillaceous rocks with quartz veins in the region of Diamantina, Brazil. Amer. J. Sci., 7:343-356, 1899 https://doi.org/10.2475/ajs.s4-7.41.343

DERBY O.A. Notes on certain schists of the gold and diamond regions of eastern Minas Geraes, Brazil. Amer. J. Sci., 10:207-216, 1900a https://doi.org/10.2475/ajs.s4-10.57.207

DERBY O.A. Notes on monazite. Amer. J. Sci., 10:217-221, 1900b https://doi.org/10.2475/ajs.s4-10.57.217

FLOYD P.A.; WINCHESTER J.A. Identification and discrimination of altered and metamorphosed volcanic.rocks using immobile elements. Chem. Geol., 21:291-306, 1978 https://doi.org/10.1016/0009-2541(78)90050-5

HENRY D.J.; SUN H.; SLACK J.F.; DUTROW B.L. Tourmaline in meta-evaporites and highly magnesian rocks: Perspectives from Namibian tourmalinites. Eur. J. Mineral., 20:889-904, 2008 https://doi.org/10.1127/0935-1221/2008/00201879

HILL I.G.; WORDEN R.H.; MEIGHAN I.G. Yttrium: The immobility-mobility transition during basaltic weathering. Geology, 28:923-926, 2000 https://doi.org/10.1130/00917613(2000)28<923: YTITDB $>2.0 . \mathrm{CO} ; 2$

MCDONOUGH W.F.; SUN S. The composition of the Earth. Chem. Geol., 120:223-253, 1995 https://doi.org/10.1016/0009-2541(94)00140-4
MITCHELL R.H.; BELL, K. Rare earth element geochemistry of potassic lavas from the Birunga and Toro-Ankole regions of Uganda, Africa. Contrib. Mineral. Petrol., 58:293-303, 1976

MORAES L.J.; GUIMARÃES D. The diamondbearing region of northern Minas Geraes, Brazil. Econ. Geol., 26:502-530, 1931 https://doi.org/10.2113/gsecongeo.26.5.502

PALMER M.R.; SLACK J.F.. Boron isotopic composition of tourmaline from massive sulfide deposits and tourmalinites. Contrib. Mineral. Petrol., 103:434-451, 1989 https://doi.org/10.1007/BF01041751

PEARCE, J.A. A user's guide to basalt discrimination diagrams. In: D.A. Wyman (ed.) Trace element geochemistry of volcanic rocks: Applications for massive sulphide exploration. Short Course Notes, 12, 1996 Geological Association of Canada, p.: 79-113.

RUDNICK R.L.; GAO S. Composition of the continental crust. In: H.D. Holland; K.K. Turekian (eds.) Treatise on Geochemistry, 3, Elsevier, Amsterdam, p.: 1-64, 2003 https://doi.org/10.1016/B0-08-043751-6/03016-4

SANEMATSU K.; MORIYAMA T.; SOTOUKY L.; WATANABE Y. Mobility of rare earth elements in basalt-derived laterite at the Bolaven Plateau, southern Laos. Resource Geol., 61:140-158, 2011 https://doi.org/10.1111/j.17513928.2011.00155.x

VALETON I.; SCHUMANN A.; VINX R.; WIENEKE M. Supergene alteration since the Upper Cretaceous on alkaline igneous and metasomatic rocks of the Polos de Caldas ring complex, Minas Gerais, Brazil. Appl. Geochem., 12:133-154, 1997 https://doi.org/10.1016/S0883-2927(96)00060-1 